\title{
Medicine and Religion
}

\section{Conscience and responsibility}

\author{
JAMES WATT
}

Those of us who have followed the editorial policy of the British Medical fournal during the past decade will have noticed increasing emphasis on ethical problems. They are posed by the changing character of medical practice in response to rapid technological advance, the pressures of public opinion ultimately reflected in more liberal legislation, and the deficiencies of a comprehensive National Health Service grappling with the problem of finite resources and infinite demand which confront the doctor with conflicting moral choices.

We may also have concluded that any philosophical discussion on medical ethics too often leads to abstract and inconclusive intellectual argument-neither conducive to postprandial reflection nor necessarily relevant to the insistent demands on the busy practitioner throughout his day. In these the patient will expect the doctor to discharge his contractual obligation to him through what he rightly considers to be his due: the knowledge, experience, and clinical or administrative skills of an expert operating under the protective moral umbrella of some ill-understood, but hopefully all-embracing, professional code.

The problem is that while the doctor is bound by that code to act responsibly towards his patient, the patient, whose expectations have been immoderately fuelled by the media operating under a code determined by the contemporary mores of our increasingly profane society, is under no obligation to reciprocate. Therein lies the doctor's moral dilemma between his conscience and his responsibility.

\section{Responsibility}

Responsibility rested lightly on the shoulders of our predecessors within their strictly circumscribed practice of preventive or therapeutic medicine over which they exerted a powerful personal influence, and a Christian definition of the Hippocratic code was generally adequate for doctors instructed in Biblical precepts. That is no longer so. The doctor's personal responsibility for his patient is often superseded by the corporate responsibility of group practices or a team of hospital specialists and paramedical personnel. He may be subject to pressures from his employing authority to implement policies of which he does not approve and to modify his clinical practice in a manner that he believes may be inimical to his patients' ultimate welfare. $\mathrm{He}$ is pressed by his patients to interrupt natural somatic processes for social convenience, and he has the unenviable task of counselling families with genetic defects and incurable diseases. He may be required to accept responsibility for medical research on human subjects and for a plethora of problems-clinical, social, and iatrogenic-caused by modern technology. In this regard Dr Michael Webb-Peploe ${ }^{1}$ has

Address given at the Christian Medical Fellowship Breakfast, Newcastle upon Tyne, 9 July 1980 .

7 Cambisgate, Wimbledon, London SW19 5AL

Surgeon Vice Admiral Sir JAMES WATT, FRCS, FRCP drawn attention to two serious dangers of the trend towards mechanisation in medicine. The danger in devoting more and more attention to what the machine says about the patient than to what the patient says about himself and the danger, foreseen by Bertrand Russell, of the immense power that the machine places in the hands of its operator against whom the patient feels utterly defenceless. "Arrogance on the one hand, apathy on the other: are these" demands Webb-Peploe "to be the hall-marks of the doctor-patient relationship of the future ?"

He might well ask, for René Sédillot, ${ }^{2}$ who sees our present age in a historical perspective, finds it infatuated with itself and with the religion of progress. Yet machinery, he observes, has not brought freedom to mankind; it has merely altered the form of his slavery - a view with which the patient on haemodialysis would agree-while advances in medicine "have served paradoxically enough to lower the quality of the human race by keeping alive the weak and the diseased at a time when violence is eliminating the fit." The responsibility of the profession is therefore immense. Doctors have already been called the arch-priests of society by the popular press, and Alvin Toffler $^{3}$ expresses the fears of his less articulate fellowlaymen about "the ethical, moral, and political questions raised by the new biology." In fact, Neyfakh, head of research in the Institute of Development Biology in the Soviet Academy of Sciences has confidently predicted the genetic equivalent of the arms race, ${ }^{4}$ and the French biologist, Jacques Ruffié, ${ }^{5}$ believes that genetic enhancement will prove necessary to ensure survival amid the frightening intellectual demands of tomorrow's world. No wonder the layman is worried about the immense potential for good and evil residing in the hands of the medical and allied professions, particularly when limited resources and substandard facilities are reducing the quality of the routine care that the ordinary patient should be able to expect. In this situation, Toffler, ${ }^{6}$ who recognises that reckless attempts to halt technology produce results as destructive as reckless attempts to advance it, calls for the appointment of a technological ombudsman to regulate its growth and direction, since nobody appears to be in charge.

For that reason, the new BMA Handbook of Medical Ethics? represents a commendable attempt to steer the individual practitioner through the minefield of increasingly complex responsibilities for which he is accountable to a society that has dispensed with spiritual imperatives in favour of human rights. As Dr Edward Norman ${ }^{8}$ showed in his memorable 1978 Reith Lectures, "Christianity today is ... notable for its lack of a distinctly Christian attitude towards the world it wishes to see changed. It has progressively borrowed ... even its tests of moral virtue, from the progressive thinking of surrounding secular culture." Professional bodies such as the BMA, therefore, find themselves required to interpret their responsibilities in this field without authoritative Christian opinion. The Central Ethical Committee is therefore to be congratulated on taking the courageous and positive step of providing guidance concerning ethical dilemmas even though, as Dr Michael Thomas' admits, there are imperfections; for Van der Sluis, ${ }^{10}$ in his admirably documented review of the movements for euthanasia 
during the past hundred years, has shown the danger of doing nothing. It was the silence of the German medical profession in the prewar years that allowed such movements to gain acceptance in Germany. We therefore stifle conscience, which is the antenna of responsibility, at our peril.

An awakening of the human conscience occurred on a world scale between the sixth and fourth centuries before Christ through Hippocrates, Plato, and Aristotle among others in Greece; Confucius and Lao-tse in China; Buddha in India; and the great Hebrew prophets thundering out their call to national repentance in Israel. In this remarkably coordinated way, it seems mankind was simultaneously prepared for the coming of Christ, who showed that neither legal proscriptions nor ethical codes provided adequate safeguards, either in private or in professional life, without an external standard of reference which He unequivocally claimed to provide as Son of God.

As Christianity was propagated world-wide so a Christian interpretation of ethics became enshrined in the concept of individual accountability to God, for both personal conduct and personal responsibility on behalf of others, guided not by rules, but by a conscience sensitised to right and wrong through that absolute and enduring standard of reference-Jesus Himself.

\section{Painful rediscovery}

It is therefore the tragedy of our newly agnostic generation that we are painfully rediscovering that no written code is, of itself, adequate to meet the changing nature of professional responsibility. Indeed, the chairman of the BMA's Central Ethical Committee ${ }^{9}$ has acknowledged that its recent handbook is already in need of revision, and 14 new ethical dilemmas are currently being debated. That something more than an ethical code is necessary is acknowledged by responsible members of the profession who wrestle with the problem. Pellegrino, ${ }^{11}$ for instance, would impose on every doctor the commitment to "systematically analyse and rationally justify" his moral choices, a discipline that Thomasma ${ }^{12}$ recognises as an essential supplement to the observance of professional codes that he believes are merely subjecting the doctor to "a minimalist approach to both ethical judgment and professional behaviour." Yet neither suggests any reliable criterion by which such ethical analysis might operate. In such circumstances the practising Christian has a distinct advantage as William Law ${ }^{13}$ explained in 1726: "A devout man makes a true use of his reason. He lives by a law which is not visible to ordinary eyes, he enters into the world of the spirit."

That is not to say that a Christian conscience is infallible, for the Christian's evaluation of any ethical problem depends on his own spiritual maturity, the quality of his spiritual life at that particular time, and its influence on his ability to appreciate the various nuances in any given situation about which it is his Christian duty to be fully informed. Otherwise, one man's conscience may become another man's work load. The inconstant sensibility of conscience was well illustrated by two of the leading abolitionists during the great eighteenthcentury debate on the slave trade. John Newton, ${ }^{14}$ the captain of a slave ship converted to Christianity, took 32 years after leaving the trade to write his influential anti-slavery pamphlet. "I think I should have quitted it sooner had I considered it as I do now to be unlawful and wrong. But I never had a scruple on this head at the time." On the other hand, James Ramsay, a Christian surgeon on board HMS Arundel, was so appalled by what he saw of the slave trade during his service in the West Indies that he persuaded his captain, Sir Charles Middleton, later Lord Barham, to urge Wilberforce to take up the matter in Parliament, and Ramsay, in 1784, was first to arouse public opinion in the campaign which led to the eventual abolition of slavery in the British colonies.

A sensitive and discerning conscience is therefore a necessary accompaniment of any moral code, for without it we find ourselves in danger of being shipwrecked on either the Scylla of utilitarianism providing the greatest good for the greatest number or in the Charybdis of existentialism where only the individual matters. ${ }^{15}$

\section{Guidelines}

Nevertheless, we search in vain for any Christian manifesto which clearly declares the relationship between conscience and responsibility, although the recent attestation proposed by the Christian Medical Fellowship ${ }^{16}$ goes some way towards it. We have therefore to go back to the seventeenth century to find a succinct and convincing Christian protocol for the safe practice of medicine. ${ }^{17}$

Those principles are equally valid today. Restated, they are: to honour God by observing His standards of practice through a conscience sensitive to His direction; to respect, learn from, and co-operate with our colleagues; to cultivate a personal relationship with our patients based on adequate communication, mutual trust, and availability; and to regard, as a duty both to God and to them, the acquisition of an ever-growing corpus of knowledge and experience that will provide the basis for our own distinctive contribution to medicine. Yet the converse is equally true, for to practise medicine without a wholesome regard for Christian values will lead to errors of moral judgment. To fail to respect our mentors and reject the experience our colleagues have to offer is to destroy the team spirit essential to harmonious collaborative effort. To fail to communicate effectively with our patients and to be unavailable to them during a crisis is to forfeit our right to treat them. To fail to acquire new knowledge and new skills or to stimulate new thinking makes us unworthy of our not inconsiderable remuneration.

\section{Envoi}

For the last word, we must turn to the Bible, and there is no better synopsis of the relationship between conscience and responsibility than that which is to be found in the first epistle of John"18: "If our conscience condemns us, God is greater than our conscience and knows everything. ... If our conscience does not condemn us, then we can approach God with confidence and obtain from Him whatever we ask because we are keeping His commandments and doing what He approves."

\section{References}

1 Webb-Peploe MM. The challenge of medical education. London: Christian Medical Fellowship Publications, 1976:9.

2 Sédillot R. A bird's-eye view of world history. London: Harrap, $1959: 264-5$.

3 Toffler A. Future shock. New York: Bantam Books, 1971:199.

4 Zorza V. Spectre of a genetic arms race. Guardian Weekly 1969;Dec 13:6.

5 Ruffié J. De la biologie à la culture. Paris: Flammarion, 1978.

- Toffler A. Future shock. New York: Bantam Books, 1971;431-2:442.

7 British Medical Association. The handbook of medical ethics. London: BMA, 1980.

${ }^{8}$ Norman E. Ministers of Change, The Reith Lectures. The Listener $1978 ;$ Nov $9: 602$.

- Thomas M. BMA News Review. 1980;January:32.

10 Van der Sluis I. The movement for euthanasia 1875-1975. Fanus 1979 ; 66:131-72.

11 Pellegrino ED. Ethics and the moment of clinical truth. $\mathcal{F A M A} 1978$; 239:960.

12 Thomasma DC. Human values and ethics: professional responsibility. $1979 ; 75: 533-6$.

${ }^{13} \mathrm{Law}$ W. A serious call to a devout and holy life. London:1726, 285.

14 Newton I. Thoughts upon the African slave trade. London: 1788.

15 Campbell AV. Moral dilemmas in medicine. Edinburgh: Churchill Livingstone, 1972:42-3.

${ }^{16}$ Christian Medical Fellowship. Christianising the Hippocratic oath. In: Service of medicine. London: CMF Publications, 1979:99:1-8.

17 Woodall J. The office and duty of the surgion's mate. In: The Surgion's Mate. London, 1617.

181 John 3, 20-2 (New English Bible).

(Accepted 9 September 1980) 